\title{
Challenges of Rural Women in Agricultural Production and Food Sufficiency in Cross River State, Nigeria
}

\author{
Uno Ijim Agbor, Ph.D \\ Department Of Public Administration \\ University Of Calabar. Calabar, Nigeria \\ Felix Onen Eteng, Ph. D \\ Department of public administration \\ University of Calabar. Calabar, Nigeria
}

\begin{abstract}
This study focuses on the involvement of women in agricultural production in Cross River State, Nigeria. The objective is to ascertain the contributions of women to food sufficiency in the state and the challenges they face in course of their farming process. The study attempted to answer the following research questions; what is the level of contribution of women in agriculture to food sufficiency in Cross River State? What are the inhibiting challenges to agricultural production by women in Cross River State? A total of 900 women across the State were examined to capture their involvement and contribution to agricultural production as well as the challenges they face in this process. Data was generated through questionnaire, interview and observation and were analyzed with simple percentage technique and presented on tables and graph. The study discovered that women in agriculture in cross river are active contributors to food sufficiency through the remarkable increase in their crop production index. Second; women are faced with challenges that inhibit robust food production in the state such as land restriction, limited access to capital/access to credit, gender inequality/discrimination and lack of storage facility. On the basis of this the study advocates policy change to give women access to more land and credit facilities. Traditional norms that hinder women access to land be relaxed through government conscious pressure on local culture. Robust assistance to fund women agriculture should become the priority of the state and the local governments through conscious policy of soft credit facilities with minimal collateral.
\end{abstract}

Keywords: Women, Agricultural Production, Food Sufficiency, Challenges, Cross River State

\section{INTRODUCTION}

In Africa, the responsibility for taking care of the children and the elderly is borne largely by women. They also get involved substantially in agricultural labour for income and household upkeep. The contributions of women in this direction are often not captured by official statistics and this under represents the actual contributions of women to agricultural production and food sufficiency. The role women play in food production is enormous in subSahara Africa. They produce food, weed and harvest on men's fields, process post harvest produce, provide fuelwood and water, and maintain the household (IAASTD, 2009). Women are highly dynamic in their effort to sustain the household in terms of food and other family livelihood.

In most rural economies women are considered the corner stone upon which the economy is anchored. Small farmers who are mainly rural women produce over $80 \%$ of agricultural resources in Africa. They are the major food producers in Africa and are involved in over 60$90 \%$ of rural marketing (AgroNigeria, 2016). To ensure food security in terms of quantity, food 
production has to be done in a sustainable way. Women have been assisting in various capacities (farmers, farm workers, natural resource managers, (Onyemobi, 2000) to ensure this. Women play significant role in producing, processing and utilizing food resources in Nigeria (Nnadozie \& Ibe, 2000). They are known for generating food for their families and by this play significant role in National Agricultural production. However, the poverty rate among rural women involved in agriculture is extremely high (FA0, 1999).

In most localities in Africa, men are considered the head of agriculture and take all the glory attached to agricultural production. In actual sense, women are engaged in constant agricultural work more than men. Studies have shown that women play more significant and remarking role in agriculture than men. This is evidence in the significant contributions of women to food production across Africa (Booth \& Protais, 2000, Mutangadura, 2004 and Bastidas, 1999).

In KwaZulu-Natal circumstances such as male migration and the engagement of children in other endeavours outside agriculture have made women to take up more responsibilities in Agriculture (Mtshali, 2002). Women dominant involvement in Agricultural production in Africa has been attributed to several factors. Colonialism has been blamed partly for this practice. Adherence of this view claim that colonialists coerced men to take up wage labour in emerging plantations and mercantilists shops, leaving their women to till the soil for food for the sustenance of the home. Rwelamira, Phosa, Makhura and Kirsten (2000) argue that while the men worked in colonial industries, the women dominated agricultural sector. Other factors include the devastating effect of HIV/AIDS which claim the lives of many household heads (men), leaving the women with no option than to take up the responsibility of providing food for the family. The factor of laziness by most men cannot be ruled out here. In order to avoid starvation, most women in Africa take up agricultural production to sustain the home.

The labour force survey of 2007 shows that one million Africans were engaged in farming activities in the Limpopo province in the previous 12 months. About 746,000 representing 69 percent were women (Stats SA, 2007). About 95\% of these women were involved in farming to provide extra food for the society. This result confirms the non repudiated role of women in agricultural production in Africa. The confidence in women efficacy in surmounting precarious conditions is acknowledged globally. The president of Chile Michelle Bachelet said this about women; "when women are empowered and can claim that rights and access to land, leadership, opportunity and choices, economies grow, food security is enhanced and prospects are improved for current and future generations."

Agriculture is an ancient practice in all human societies. As a practice of farming, it depends heavily on the type of vegetation zone which may vary according to climatic factors. In Cross River State, this traditional practice is favoured by the annual temperature with rainfall far above $3500 \mathrm{~mm}$. Crop cultivation is therefore an all year business. Agricultural production serves as a major source of food supply for households and raw materials needed by industries. Agricultural practices serve as a major source of drugs for both orthodox and herbal treatment of sickness and diseases. It contributes significantly to the country's Gross Domestic Product (GDP) and foreign exchange earnings. Agriculture plays important role in family welfare and household income. This old practice is capital and labour intensive. This condition explains why modern youths have a persistent dislike for it because of the physical stress involved in such occupation.

A large number of the people involved in agricultural production in cross river state are women. They do this with dignity despite difficult situations. The role of women in agriculture 
is remarkably important because of the responsibility they take for domestic food sufficiency and food supply to the neigbouring states of Akwa Ibom, Ebonyi, Abia and some parts of the Cameroun Republic. Women are daily engaged in crop planting due to a number of factors: Firstly, most women consider agriculture as a good source of employment opportunity. The practice of agriculture enables the women to be self-reliant and in turn serve as employers of farm labour. Secondly, women tend to have the desire for private financial resources or income like their male counterparts. This is because relying on the men for daily family needs tend to place a burden which makes the women to be looked down upon by the men. Therefore, to avoid conflict which often arises due to constant demands, some women resort to agriculture to support the family and make "ends meet". Thirdly, many women are usually abandoned by their husbands to shoulder the feeding of their children and other household responsibilities. This traditional African problem most often than not compels the women to take to agriculture than prostitution as a route of escape from the "brute realities" of life.

In Cross River State, women involvement in agricultural production has not only improved food supply but has helped to reduce malnutrition in the state. Stable food supply in many homes have reduced poverty and hunger which usually compels the youth to engage in obnoxious activities of stealing, house breaking and vandalization of communal or public projects. Since government emphasis on supporting farmers is more towards group formation, like their counterparts in Ebonyi, Bayelsa, Rivers, Ondo, Kaduna, and Anambra States, women in Cross River State form co-operative societies to ensure quality control of farm products and create access to recognition and loan facilities. Some of these registered co-operative societies include: Young Farmers Multi-purpose Co-operative Society, Ada Ladies Multi-purpose Cooperative Society, Enyonyor Farmers Multi-purpose Co-operative Society, Macvicson Multipurpose Co-operative Society, and Ojo Women Multi-purpose Co-operative Society. Other nonregistered farmers associations include: Women Arise, August Women and Able Ladies. The various women organizations are meant to bridge the gap that exist between the women and men farmers in Cross River State. Women play essential role in agriculture in Cross River State. Their massive involvement in large scale farming has contributed to making food stuff available in the local markets for household needs. Despite this fact, much is not written on this all important role women play to guarantee food sufficiency and the challenges they face in Cross River State.

The drive by women to boost agricultural production in the state could be confronted by possible challenges which are likely to inhibit their effort at effectively contributing to food sufficiency in Cross River State. The question is could the challenge of land restriction, cultural/religious barrier, lack of farm service centers/extension services, limited capital/lack of access to credit, herder trespass, inheritance, gender inequality/discrimination, lack of storage facilities as well as lack of women participation in major decision process affect their commitment to agricultural production? This paper is a modest contribution to chronicling the contributions of women to food sufficiency in Cross River State and the challenges they face in this exercise. The broad objective therefore, is to investigate the contribution of women to food sufficiency in Cross River State as well as ascertains whether their operations are inhibited by these challenges.

\section{CLARIFICATION OF CONCEPTS}

Concepts in research are usually clarified in order to give clear meaning to the subject matter of discussion and make the research to be understood within context (Eteng \& Adie, 2016).

Agricultural Production: It is concerned, in this study with cultivating land and growing crops for consumption. In this case all the farm activities by women geared towards growing crops for both commercial and subsistence purpose falls within agricultural production. 
Challenges: Encumbrances faced that are likely to inhibit or slow the process of an activity. In this study it entails those factors that are capable of hindering the efficacy of women in agricultural production in Cross River State,

Food sufficiency: The concept of food sufficiency implies easy access to adequate food supply to individuals or communities for the purpose of good health and wellbeing. Under this condition, the prevailing situation will be that food would become affordable at low prices. It also implies the availability of food at all times. It is a guaranty to food and a right which can be measured by the following indices: accessibility, affordability, acceptability, and appropriateness of food in any environment (Olufemi, 2013).

\section{EXEGESIS ON WOMEN AND AGRICULTURE}

Women involvement in Agriculture dates back to the early man where the hunter-gatherer technique was applied (Hanson, 2017). Women fetch firewood, picked fruits, prepared drinks, gathered vegetable and food crops, cooked and serve for consumption (Dahlberg, 1981). What women gathered accounted for substantial daily needs and calorie intake of their locality (Hansen, Jensen, \& Skovsgaard, 2012). Women participation in Agricultural production has been increasing in various climes. In the United States in particular, by 2012 about 288 thousand farms were principally managed by women (United States Department of Agriculture, 2012). Women are increasingly getting involved in agricultural production and their success rate is encouraging (Hanson, 2017). In the state of Wyoming in the United States, women presence has increased tremendously in the agricultural industry (Ballenger \& Ritten, 2014, Hanson, 2017).

In Nigeria, women play significant and important role in agricultural production (Damisa, Samndi, and Yohanna, 2007). Their study revealed that the level of their disposable income, perception and tenure right and their contribution to agriculture has significantly impacted on agricultural production. Women account for over $75 \%$ of the farming population in Nigeria either working for themselves or as suppliers of labour (Federal Ministry of Agriculture and Rural Development). Women involvement in agriculture is confronted with diverse inhibiting challenges. Chikwendu and Arokoyo (2008) submit that even though 90 percent of the women in Nigeria are involved in farming even in the traditional Muslim States were 'Purdah' is still practiced, they have little control over their labour. They work in both family and personal farms. They do not have adequate security for farming as majority neither possessed nor owned land. They also do not have adequate funds for farming. Very humiliating is the fact that those who engage in paid labour are paid less than men on the same piece of job. In some localities, women were not allowed to grow tree crops so that they would not feel like land owners.

Kemi (2017), identified the challenge of inadequate capital and lack of technological knowhow as some of the challenges facing women participation in agricultural production in Akoko south West Local Government of Ondo State, Nigeria. On the other hand, Effiong (2013) locates the challenges to women participation in Agriculture within the obnoxious cultural/religious restrictions, poor health and lack of access to education. These challenges posses the capacity to reduce the productivity level of women in agriculture.

\section{Theoretical framework}

This work is anchored on the Feminization of Agriculture theory. The theory is rooted in feminist economics which explains the geometrical involvement of women in the agricultural sector especially in the developing countries. The 1960s witnessed the massive involvement of women in agricultural production and has grown tremendously over time. Studies by World 
Bank and IFAD \& FAO in 2009 discovered that over $80 \%$ of rural people worldwide engaged in agricultural activities were women. They argue that several factors accounted for this. One of which is the migration of men to seek other forms of employment outside agriculture (Robinson-Part, 2016, World Bank, FAO\&IFAD, 2009). 45-80\% of women working in the labour sector are in agriculture according to the United Nations (www.un.org/womenwatch).

Women run their farms and are heads of households where the man is dead. The size of farms cultivated by such women is often small and capable of threatening food security. The theory argues that women in Agriculture in backward societies are likely to be disadvantaged compared to their male counterparts. They have less access to production resources such as improved seeds, quality extension services, and standard tools. They are likely not to have social connections that lead to credit and market networks. This leads to what is termed investment poverty. Women suffer damaging discrimination as a result of social norms that sees man as more superior to the woman. When the men and the women are engaged on the same job, the men are paid higher than the woman. Women are seen in this case as secondary labourers.

It is considered sacrilegious for women to bargain for higher wages. This is viewed negatively and considered distressed (whitehead, 2009). The feminization of agriculture has often led to the practice of subsistence farming because of the challenges women face in agriculture production. When women do not have access to factors that can boost agricultural production they are likely to plant less with old varieties of seeds. The danger is food insecurity and escalation of rural poverty. The popularizers of this theory include. Boserup (1976), Reardon (1995), Deere (2009), Razavi (2009), Whitehead (2009).

\section{STUDY AREA}

This study was conducted in Cross River State, Nigeria. Cross River State is a coastal state which is found in the Niger Delta Area of Southern Nigeria with seasonal heavy rainfall that favour agricultural production. The state occupies about 20,156 square kilometers and is predominantly rich in agriculture and solid mineral resources. Cross River State is made up of many ethnic groups with diverse languages. The various ethnic groups have produced a "Tower of Babel" which is highly demonstrated by nearly kilometer to kilometer differences in language. Some of these ethnic groups include: Bekwarra, Nkum, Ukelle, Ejagham, Mbembe, Yakurr, Bahumuno, Agbo, Biase, Quas and Efiks.

The state consists of eighteen local government areas that are grouped under three geopolitical zones, namely: North, Central, and South. The North consists of Obanliku, Obudu, Bekwarra, Yala, and Ogoja. In these local government areas, women are predominantly involved in agricultural production of oil, honey, groundnut, cassava (used for garri processing) beans, rice, maize, bene-seed, millet, sugar cane, yams, and "dawa-dawa" (Locust beans - a form of spices for cooking). The state depends on this area for yams and garri supply.

The central geo-political zone is made up of Boki, Ikom, Etung, Obubra, Abi, and Yakurr. The area is rich in yams and cassava production. Other items include: plantain, pineapple, banana, vegetables and palm oil. Many biscuits and fruit juice industries in the country depend heavily on the banana and pineapple supply from the area for regular industrial production of biscuit and fruit juice. Again, women in this area play dominant role in food supply for household consumption, and to the neigbouring states of Ebonyi and Akwa Ibom State.

The South consists of Biase, Akamkpa, Odukpani, Akpabuyo, Bakassi, Calabar South and Calabar Municipality as units of local government areas. The Southern Senatorial District is 
predominant in fish supply from the Creeks and the riverine areas around Odukpani, Akpabuyo and Calabar South. Vegetables, garden eggs, cucumber, avocado pears, oranges, pineapples, cassava, plantain and maize are supplied from this area. The major role of women in agriculture in the South has helped to sustain food supply in the teeming urban population of Calabar Metropolis.

\section{METHODOLOGY}

This study is a survey of the contribution of women to food sufficiency in Cross River State and the challenges they face in this process. It is essentially therefore a survey research. Data for the study was generated through questionnaire and was analyzed with percentage technique and presented on tables and graphs. The use of secondary sources such as books and documents provided the theoretical background of the study.

\section{RESULTS AND DISCUSSION}

\section{WOMEN, FOOD PRODUCTION AND FOOD SUFFICIENCY IN CROSS RIVER STATE}

TABLE: 1. Food production profile of women in Agriculture in Cross River State

\begin{tabular}{|l|l|l|l|}
\hline S/N & LOCATION & AGRICULTURAL PRODUCT & $\begin{array}{l}\text { QUANTITY PRODUCED PER } \\
\text { MONTH (METRIC TON) }\end{array}$ \\
\hline 1 & ABI & Rice, Cassava (Garri) & 20 (rice) 40 (garri), \\
\hline 2 & AKAMKPA & Maize, Vegetable, Cassava & 5,50 respectively \\
\hline 3 & AKPABUYO & Maize, Palm oil & 10 (Maize), 100 (palm oil) \\
\hline 4 & BAKASSI & Fish, crayfish, periwinkle & $1000,1200,1500$ \\
\hline 5 & BEKWARRA & Groundnut, Pepper, tomatoes & $10,15,5$ respectively \\
\hline 6 & BIASE & Cassava (garri), Yam, plantain & $45,60,30$ respectively \\
\hline 7 & BOKI & Pineapple, plantain, Banana & $50,300,400$ respectively \\
\hline 8 & CALABAR MUNICIPAL & Vegetable, Piggery & 200,50 respectively \\
\hline 9 & CALABAR SOUTH & Vegetable, Poultry, Fishing & $250,200,230$ respectively \\
\hline 10 & ETUNG & Cocoa & 1000 \\
\hline 11 & IKOM & Cocoa, Fruits & 1000,1200 respectively \\
\hline 12 & OBANLIKWU & Cassava(garri), sweet potato & 30,10, respectively \\
\hline 13 & OBUBRA & $\begin{array}{l}\text { Cassava (Garri), Yam, Maize, } \\
\text { Rice }\end{array}$ & $200,80,40,25$ respectively \\
\hline 14 & OBUDU & Bene seed, locust beans, yam & $10,12,70$ respectively \\
\hline 15 & ODUKPANI & Cassava(starchy fibre) & 200 \\
\hline 16 & OGOJA & Yam, Rice, Cassava (Garri) & $100,100,200$ respectively \\
\hline 17 & YAKURR & Yam, Cassava (garri) & 80,200 respectively \\
\hline 18 & YALA & Yam, Rice, sweet potato & $75,25,20$ respectively \\
\hline
\end{tabular}

Source: Fieldwork, 2018

Greater involvement of women in commercial agriculture is in the area of cassava cultivation. Cassava is used to produce garri and fermented starchy fiber. They are major staple food consumed largely in the area and beyond. Because of its high demand in homes, indulging in cassava production is a guarantee of stable income. This aptly explains why most women across the state are deeply involved in its cultivation.

Most women farmers in cross river state operate at a smallholder or subsistence level. Despite several challenges, women have been the fundamental pillars on which rest food production and food sufficiency in cross river state. Unlike the men, women take the lead in the cultivation of crops and other food items like cassava, maize, yams, banana, plantain, and potatoes. Women are prominent in the production of vegetables, cucumber, tomatoes, lemon, millet and 
onion. Generally, women play active role on the rice value chain. For instance, at various production processes of rice, they play big role in transplanting and harvesting of rice. In most cases, they incur high cost to produce rice, cassava and maize due to the cost of land preparation. Despite the high cost of land preparation which usually affects the cost of food, the study observed that women involvement in agricultural activities has enhanced food sufficiency and averted the usual predicament of food crisis in the state. Most households can now boast of food supply and consequently hunger is reduced considerably. This gives hope to many families across the state.

Women play greater role in poultry farm activities than men. The supply of eggs and chicken at regular basis has helped to reduce cases of Kwashiorkor and other sicknesses associated with malnutrition. A survey of selected households across the state randomly chosen indicates that a lot of nutritional values like protein and vitamin are daily provided in many households as a result of fish, vegetables and food crops supplied by women through agricultural activities. Crops like water melon, beans, cucumber, oranges and onions are produced by women and are vital for healthy living. These farm activities of women in no small measure help to sustain life and reduce mortality rate among children, the aged, and women of child bearing age.

Women in the State are greatly engaged in animal husbandry to improve household income. Most women breed animals on a farm at a large scale. Many rear goats, sheep, pigs and native chicken as a source of meat supply and income generating business. This practice serves as a means to provide school fees for their children and enable them to meet other farm needs. Women's role in fish farming is also enormous. With the use of running water provided by the coastal terrain or ponds created in some cases especially in Calabar South, Akpabuyo and Bakassi, women contribute significantly to fish supply in the state. This practice has been the source of income to many households especially along the creeks and riverine areas. Fish farming has been the source of fish protein as a nutritional value for healthy living. It is also source of food supply to many homes. It provides oil for industrial use.

The role of women in food production and food sufficiency in cross river state has significantly contributed to poverty and hunger reduction. Many households rely on the proceeds from the farms to meet their demands and enjoy a peaceful family life. Income generated through food production can now be used for clothing, health maintenance, and possibly provide shelter for households that have no roof over them.

The practice of agriculture is predominantly controlled by women than the men. Indeed, women are the major food suppliers in rural and urban areas of the state. A survey of women in agriculture in many rural and urban areas shows that in cross river state women are seriously engaged in agriculture as income generating occupation. Women are no longer to be considered as mere spectators watching the men but as active participants in agricultural production. Some of the women involved in agriculture are educated and well to do. Therefore, they participate seriously in farm management practices in order to improve agricultural productivity.

Experience from the rural areas of the State clearly shows that a wide gap exist between women and men farmers. Women's role in agriculture is strictly limited by the activities of men in decision making process. For instance, this study observed that women are not allowed to decide where to farm or select site for annual farm cultivation. The responsibility rests entirely with the men who take the lead to arrange where seasonal farming can take place. However, in some communities it was also observed that the aged women are allowed to participate in decision making process. 
In terms of labour input, women have demonstrated strength greater than that of men and by so doing contributed more to agricultural production. An investigation of most rural communities across the state revealed extensively the contribution of women towards agricultural production and food supply to many households despite the stress. In some parts of Calabar South for instance, the study observed that daily a large number of women are engaged in crops and vegetable planting while their male counterparts are busy in other social activities. Most of the women interviewed maintained that they usually obtain loan and other credit facilities for purpose of procuring manure or fertilizer for farm use. This practice greatly enhances food supply in the area.

In some other communities in the state especially the central and northern geo-political zones, the study observed that women labour is often hired and this helped to improve their income. In many instances, women group themselves into organized team labour to facilitate work process in farm activities. This has helped to ease such tedious farm work as making mounts, weeding of grass, clearing of the bush and bush burning. The process saves cost, reduces stress and promotes unity among the women in agricultural practice.

Therefore, like the Jukun women in northern Nigeria, women are taking the lead in agricultural activities in the State. They receive little or no assistance on training on value addition and how to improve production practices on cassava, rice, and maize. Similarly, the women farmers have no assistance from World Bank or Government despite huge amount annually expressed in budgetary allocation for agriculture. Such monies often end up in the hands of the politicians who in their prebendal practices decide who the beneficiaries should be based on support at electioneering campaigns.

Women have been involved in agricultural activities over the years contributing their quota to food sufficiency in the state. Table 2 below shows the statistical index of crop production by small holder farmers ('000 metric tons) in Cross River State from 1999 to 2009.

Table 2. Statistical Index Of Crop Production By Smallholder Farmers (1000 Metric Tonnes) In Cross River State: 1999-2009

\begin{tabular}{|l|c|c|c|c|c|c|c|c|c|c|c|}
\hline $\begin{array}{l}\text { Types of } \\
\text { Crops }\end{array}$ & $\mathbf{1 9 9 9}$ & $\mathbf{2 0 0 0}$ & $\mathbf{2 0 0 1}$ & $\mathbf{2 0 0 2}$ & $\mathbf{2 0 0 3}$ & $\mathbf{2 0 0 4}$ & $\mathbf{2 0 0 5}$ & $\mathbf{2 0 0 6}$ & $\mathbf{2 0 0 7}$ & $\mathbf{2 0 0 8}$ & $\mathbf{2 0 0 9}$ \\
\hline $\begin{array}{l}\text { Cassava } \\
\text { Tuber }\end{array}$ & $2,044.9$ & $1,958.0$ & $1,957.3$ & $2,017.3$ & $1,125.2$ & $1,254.0$ & $1,441.8$ & $1,587.7$ & $1,587.7$ & $1,733.3$ & $1,753.06$ \\
\hline Yam Tuber & $1,356.2$ & $1,256.0$ & $1,256.0$ & $1,288.0$ & $1,312.0$ & $1,403.1$ & $1,504.1$ & $1,830.0$ & $2,043.5$ & $2,814.9$ & $3,268.0$ \\
\hline Cocoyam & 186.0 & 193.0 & 193.0 & 197.0 & 210.0 & 212.1 & 220.3 & 230.2 & 244.8 & 259.5 & 275.1 \\
\hline $\begin{array}{l}\text { Sweet } \\
\text { Potato }\end{array}$ & 20.0 & 20.0 & 19.0 & 19.0 & 19.1 & 19.9 & 20.2 & 21.6 & 64.0 & 212.7 & 273.4 \\
\hline Maize & 103.5 & 98.1 & 94.7 & 98.9 & 94.0 & 109.2 & 113.0 & 123.9 & 123.4 & 220.2 & 321.1 \\
\hline Rice & 0.2 & 0.2 & 0.2 & 0.3 & 0.3 & 0.3 & 1.0 & 1.1 & 45.3 & 68.0 & 175.8 \\
\hline Groundnut & n.a & 4.8 & 4.8 & 5.5 & 5.6 & 5.7 & 6.2 & 6.8 & 8.7 & 11.7 & 12.93 \\
\hline Cowpea & n.a & 6.0 & 8.0 & 8.1 & 8.7 & 9.6 & 10.1 & 10.0 & 10.0 & 6.1 & 6.34 \\
\hline Okra & 7.4 & 7.8 & 7.2 & 7.5 & 7.6 & 8.7 & 9.6 & 10.5 & 12.3 & 16.7 & 23.15 \\
\hline Pepper & 14.7 & 16.0 & 14.3 & 12.5 & 12.6 & 13.9 & 14.9 & 14.1 & 26.6 & 33.9 & 43.02 \\
\hline Tomato & 10.0 & 11.2 & 9.2 & 9.2 & 9.2 & 10.3 & 10.9 & 12.0 & 12.6 & 31.6 & 44.97 \\
\hline $\begin{array}{l}\text { Garden } \\
\text { Egg }\end{array}$ & 4.0 & 4.1 & 2.2 & 2.3 & 2.3 & 2.6 & 2.7 & 2.8 & 4.5 & 5.8 & 7.27 \\
\hline
\end{tabular}

Source: NPAFS, FMA \& WR, Abuja.

When we take a comparative assessment of the agricultural production index of some crops between 2009 and 2018 there is a remarkable improvement in the quantity of farm produce by rural women. Table 3 captures this difference vividly. 
TABLE 3: Difference in the production index of selected crops between 2009 and 2018 in Cross River State

\begin{tabular}{|l|l|l|l|}
\hline S/N & TYPES OF CROPS & $2009(000$ metric tons $)$ & $2018(000$ metric tons $)$ \\
\hline 1 & Yam & $3,268.00$ & 5,580 \\
\hline 2 & Cassava (Garri) & $1,753.06$ & $11,500.00$ \\
\hline 3 & Maize & 321.10 & 660.00 \\
\hline 4 & Rice & 175.80 & $2,040.00$ \\
\hline 5 & Groundnut & 12.93 & 120.00 \\
\hline 6 & Sweet Potato & 273.40 & 360.00 \\
\hline
\end{tabular}

CHALLENGES OF WOMEN IN AGRICULTURAL PRODUCTION AND FOOD SUFFICIENCY

The women were presented with a guided questionnaire and were asked to respond to each of the questions on the challenges as they affect them in the course of their engagement in agricultural production. The result is as presented on the table below.

Table 4: Responses on the challenges faced by women in agriculture in Cross River State

\begin{tabular}{|l|l|c|c|}
\hline S/N & Challenges & Frequency & Percentage \\
\hline 1 & Land restriction/Limitation & 870 & 96.66 \\
\hline 2 & Cultural/ Religious Barrier & 70 & 7.77 \\
\hline 3 & Lack of farm service centres/Extension Services & 100 & 11.11 \\
\hline 4 & Limited capital/Access to credit & 700 & 77.77 \\
\hline 5 & Herders trespass & 20 & 2.22 \\
\hline 6 & Inheritance & 60 & 6.66 \\
\hline 7 & Gender inequality/Discrimination & 600 & 66.66 \\
\hline 8 & Lack of participation in decision making & 300 & 33.33 \\
\hline 9 & Storage facility & 750 & 83.33 \\
\hline
\end{tabular}

Source: Fieldwork, 2018

The table above shows that 96.66 percent of the women sampled faces the challenge of land restriction/limitation. They consider this a major encumbrance to their involvement in agricultural activities. Cultural/ Religious factor attracted 7.77 percent. The women do not consider this factor as major challenge to their farming activities. Lack of farm service centres/Extension services was considered by 11.11 percents of the respondents a challenge. Greater portion of the women do not see it as a major factor. Extension services has a little to do with minimal education and since majority of rural women in agriculture are illiterates they are likely to led by superstition and may not take the advice of extension officers as necessary factor in their production profiles. The factor of capital and access to credit emerged disturbing. 77.77 percent of the respondents are confronted with the challenge of limited capital and lack of access to credit. This factor is a serious challenge to women who are into commercial farming. Majority wants to increase their farm sizes for increase harvest for the market. Limited finance becomes a serious setback for such women. Women engaged in subsistence farming and minimal commercial desires are largely not affected by limited finances.

The challenge of herder trespass attracted a response rate of 2.22 percent. This an indication that this challenge is not major set for women in agriculture in Cross River State. This could be explained from the point that Cross River State does not engage in heavy pastoral farming as is the case in the middle belt region of Nigeria. Inheritance right as a factor plays limited role farming activities of women in cross river state. The percentage of women farmers affected by this challenge was 6.66. Gender inequality and discrimination is another major challenge to women in agriculture in cross river state. 66.66 percent of the women sampled see it as a major setback. The portion of land often given to women for farming exercise is grossly smaller 
compared to what their male counterparts receive. In some communities women are allowed to open virgin forest for farming. It is the exclusive right of men. In such communities women are pushed to over cultivated portions of land which adversely affects their yield. Participating in decision making got a response rate of 33.33. Less than 50 percent of the respondents see it as challenge. The decision on where to farm for most communities in cross river state is taken by the men. Women do not make any input to that decision. Very worrisome is the fact in some communities there are designated days set aside to harvest cassava; a major source of revenue for the rural woman farmer. Such restrictions put by men affect women's return on farm investment in rural areas. Storage facility is considered a major challenge to women investment in farming in Cross River State. 83.33 percent of the respondents consider it a major encumbrance. Over 30 percent of farm produce get spoil every week in rural communities. This tells negatively on the profit margin of such farmers. The degree of challenges to the women is presented on figure 1 below.

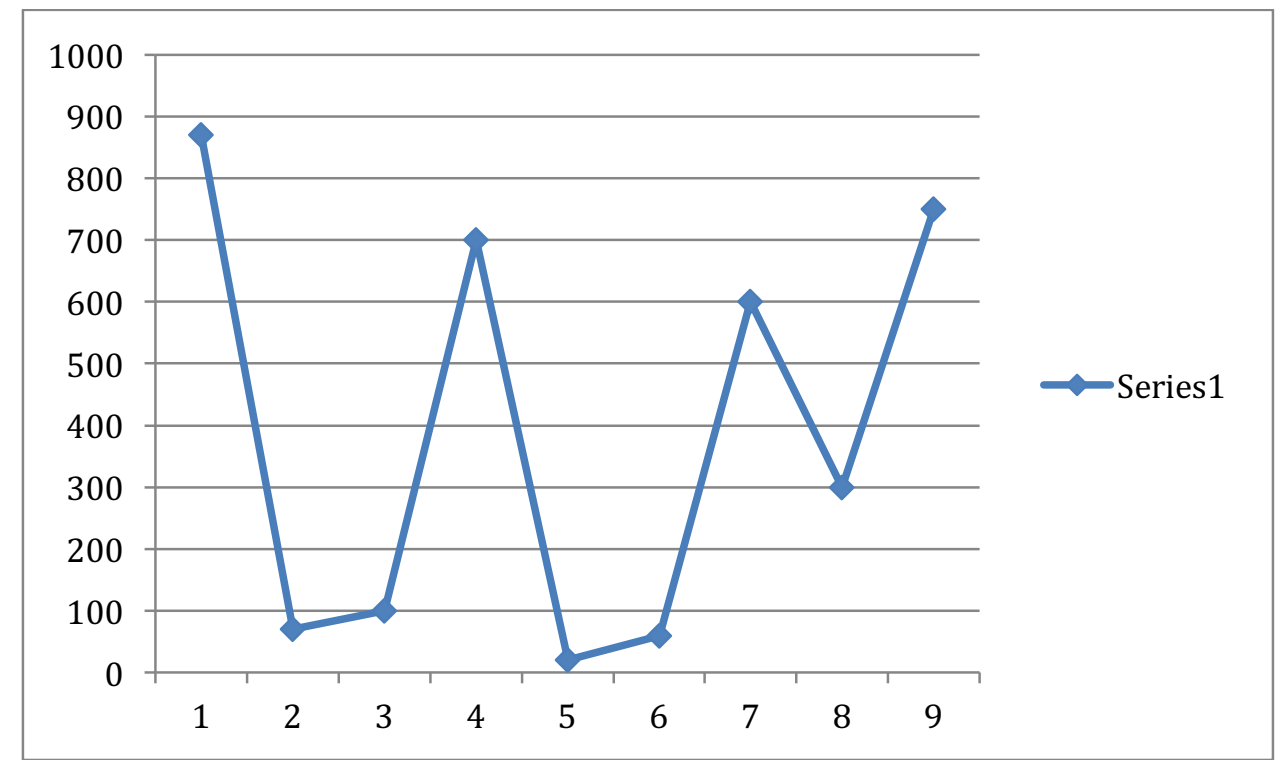

Fig.1. Frequency distribution of the challenges to agricultural production faced by women in Cross River State.

Challenges 1, 4, 7 and 9 which involves land restriction, limited capital/access to credit, gender inequality/discrimination and storage facilities respectively account for the major challenges women face in agricultural production in Cross River State.

\section{Land restrictions/Limitation}

Land is the foundation of agriculture. It is the corner stone upon which agricultural activities sufficiently takes place. A reduction in access to it determines what quantity of crops a rural woman can cultivate at a given point in time. Rural women are confronted with limited access to land and this has remained a major encumbrance to large scale farming. Majority of rural women depend on land for survival yet as argued by Shezongo (2005) the relationship between women and land is that of insecurity and lack of control. Assumptions by most policy planners and rural men dominated leadership in the allocation of land to women is predicated as pointed out by Zwarteveen (1996) on the claim that women produce little compared to men. This certainly is not true in Cross River State. The men are not outstandingly involved in agricultural production than the women. Women produce far more than the men. Kemi (2017) discovered also that land ownership constitutes a problem for women in agriculture in Akoko west local government in Ondo state. It is obvious therefore, that limited access to land is a major threat to women contribution to food sufficiency in Cross River State. 


\section{Limited capital/Access to credit Facilities}

Access to credit facilities in the form of loan or grants given to women farmers in the state is absent in most cases and considerably low in some. Credit facilities such as the ones organized by agencies like LAPO or FADAMA in the state cannot sustain a high level of women participation in farming. Some of these organizations barely grant a loan or credit facilities above one hundred thousand naira ( $\$ 100,000.00)$. This is an insufficient credit system which can hardly promote extensive agricultural practices. Besides, the conditions attached to obtaining such loans are stringent. Inability to repay these loans often results in the carting away of the property of the borrower. This harassing condition makes many women to feel reluctant to obtain loan which could have been invested in agricultural food production.

The microfinance institutions created to be of service to the women farmers does not solve the problem either. Apart from the stringent conditions attached to obtaining the loan, the procedure for procuring such loan is hazardous. Even when the loans are eventually given, the interest rate makes the conditions worse for the women farmers. In some other cases, prebendal politics by the political class is often used to determine who the beneficiaries are. Therefore, those who are not directly related to the politicians end up not having the loan. This ugly situation serves as a serious challenge to women in agriculture. The stringent conditions associated with accessing credits from the formal sectors makes rural women farmers to seek credit assistance from the informal sectors (eg. Osusu groups).Agbo and Ihemezie (2015) study of access to credit by vegetable farmers in Owerri , Imo state, Nigeria shows that 74.5 percent of the farmers studied access credit from the informal platform while 25.5 percent access credit from the established formal sector. Credit encourages large farm practice and could lead to purchase of improved varieties and other resources needed to improve agricultural production.

\section{Storage Facilities}

This is where agonies are felt. Most farm products by the women farmers are perishable and need to be stored in a cool house. Plantain, Banana, Tomatoes, vegetable, cucumber, pears and pineapples need to be stored to avoid perishing. Also the absence of warehouses for food storage worsened the already existing precarious condition of storage in the state. With poor transport system and bad roads, most of the farm products cannot be conveyed to the city for storage. This creates a serious challenge to the women farmers. Imonikebe (2010) also discovered this as a major setback to rural women in agriculture while studying their constraints in food production in the western and eastern part of Nigeria.

\section{Gender Inequality/Discrimination}

Gender inequality is commonly expressed among many communities in the form of inequality in the exercise of power, social responsibility, division of labour, and distribution of natural resources. All over the state, women are socially discriminated against being considered as second class individuals to men. When it comes to allocation of land for farming, women are allocated smaller portion compared to the male counterpart. No woman participates in the allocation process. It the exclusive reserve of men. What this means is that whatever dimension of land is allocated to a woman that is what takes. In cases where land is owned by families, women are discriminated against as the male members of the family determine what portion of land goes to the women. Smaller portion of land allocated to women arising from this cultural dimension of discrimination challenges the volume of women involvement in commercial agriculture. Women are not granted the right to participate in decision making process and can hardly assemble with their male counterparts in the village council for important matters. They are expected to carry out domestic responsibilities of food supply and child bearing. In almost all the rural areas, the study observed that women are taken as a room 
in a house that can easily be annexed by a man. This is the plight of women which creates inferiority complex among them and seriously hinder women to make progress in a male dominated society. Discrimination against women in agriculture is still common. Michalopoulos (2018) writing for EURACTIV observed that women discrimination in agriculture is widespread ranging from 78 percent in India to 52 percent in the United States. In the EU community, 68 percent of women farmers consider gender discrimination a major issue in agriculture. It is also a serious problem affecting women in agriculture in Cross River State.

\section{Lack of farm service centers/Extension services}

Most women do not understand what extension service is and its usefulness. This is so because such service is not even provided by the government. The danger of the absence of extension service is dominance of superstition in the farming culture of rural women. This has consistently led to planting old varieties of seeds and stems even when the yield is minimal. Women in agriculture have not enjoyed the benefit of extension service and this is noticed in their cropping pattern. Value chain centers which could serve as farm hiring centers for the women farmers are virtually absent in the State. Value chain centers need to be strategically located in each of the senatorial districts in the State. They could serve as sources of revenue or income to the government. In addition, this will help to remove frustration and stress among farmers and increase participation in agriculture and food sufficiency.

\section{Inheritance}

This is an aspect of culture that poses a serious threat to women in agriculture. In many communities across the state, women have no inheritance in the form of right to land or property from their parents or family members. The general believe is that a woman belongs to a man and has child bearing responsibility. Therefore, women cannot as a practice own any land or property except that which may belong to the husband's lineage group. In some communities, the property of a man does not go to the wife if the man dies, but can only be transferred to his siblings. This practice creates a problem among women in agricultural production. Most women rent farm lands which in some cases may not be adequate because of the cost.

\section{STRATEGIES TO BOOST WOMEN AGRICULTURAL PRACTICES AND FOOD SUFFICIENCY IN CROSS RIVER STATE}

The population of Cross River State is fast growing with the greatest challenge on food sufficiency. This problem creates a concern to all stakeholders, individuals and government. Goal two of the Sustainable Development Goal places emphasis on zero hunger which can only be achieved through food sufficiency in the society as a tool for poverty and hunger reduction. Therefore, there is need for strategic interventions as a means to improve women agricultural practices and ensure food sufficiency in the State. These interventions will include the following:

\section{Establishment of farm hiring centers}

There is need for the government to establish farm hiring centers where rent services of farm machinery or equipments are provided at ease and at low cost to the farmers on regular basis. This will help to boost women participation in agriculture and reduce stress in farm work. Generally, the practice of agriculture is labour intensive. Therefore, these value chain centers where all things are made available will in no small measure boost women participation in agriculture as well as increase State revenue. 


\section{Research on agriculture and food sufficiency}

Research promotes development in agriculture and food sufficiency. Regrettably, agriculture and food sufficiency is affected by lack of adequate research, increase in population, low productivity and climate change (climate change may result in soil infertility and low crop yield due to extreme hot weather conditions). The importance of research cannot be overemphasized. Research provides information on how to remove waste, improve farming techniques, control plant and animal diseases, ascertain the food sufficiency level in a State as well as provide information on how to control food contamination.

Unfortunately, most of the women in agriculture and food sufficiency in the State are illiterate and cannot correlate cause and effect. Since they are not educated, they fail to appreciate the value of research in agriculture and food sufficiency. In most cases, they refuse to express confidence in the farm techniques or information obtained through research but solely lean on the traditional peasant methods bequeathed to them as inheritance from their parents. They regard the agricultural techniques taught in schools and colleges as alien with no practical realities to what is obtained in the traditional society where land is male dominated and women have no right to decision making.

Therefore, the State need to commit itself to educate the mass illiterate of women in agriculture and food sufficiency by ensuring that these people are taught the use of modern farm implements, use of fertilizer and knowledge of climate change as well as the use of improved variety of seeds. This they can do by introducing what this paper calls agricultural adult education at the rural areas. There is need for farmers to be sensitized on the value of information provided by research. This will help in improving agriculture and food supply through climate prediction and taking the right decisions.

\section{Provision of Infrastructure}

The provision of infrastructure is a major boost to crop and livestock production. The miracles in Malaysia, Japan and other Asian countries owe much to infrastructural provision. Infrastructure provides a take off base for successful crop planting and livestock production which improves the per capita income of a nation. Without infrastructure, several farm challenges like poor harvest losses, pests, diseases and storage become prevalent resulting in food contamination especially cassava and maize. Many households in the State suffer economic losses due to the absence of infrastructure. Therefore, there is need for adequate budgetary provisions to address this problem in the State.

\section{Support from Extension Services}

Establishing agricultural extension services serve as tools to support women in agriculture and food sufficiency in the State. The role of extension services is primarily to identify the women groups in the State and establish linkages that will enable these groups to acquire essential skills in agriculture as well as have direct access to the needed farm resources. Extension services are also created to give directive and carefully design several farm interventions by providing understanding and knowledge which will stimulate higher productivity in food sufficiency. This effort will require the process of disseminating information to women farmers in order to achieve the expected goal. Disseminating information is principally done through frequent meeting as well as individual or group discussion with women and other stakeholders in agriculture and food sufficiency. This creates impact especially through the use of cell phones particularly in rural communities where electronic media and newspapers are in most cases non-existent or in short supply. 


\section{Construction of Feeder Roads}

There is need to construct feeder roads to link the various rural communities in the State. This will help to evacuate food from the rural areas and promote food sufficiency in the cities. In Cross River State, the dominant food supply to the urban areas comes from the rural communities. Therefore, there is need for State intervention to properly maintain these roads and give confidence to the farmers in terms of transporting their foods and making it available at the expected price to the people. Bad roads cause high cost of transportation which in turn has a multiplier effect on food and other treasure needs of the people. Also transporters and other middlemen involve in food supply will not be able to maintain a quality standard that meet global best practices if the roads are not maintained and kept in good condition.

Although in the past government in its rural development policy have made effort towards providing feeder roads in many communities, yet this effort was never enough as many rural areas were not linked by roads. In some cases, movement from one village to another is through forest foot paths which expose people to attack by wild life. This lamentable condition calls for government intervention to bring roads to the people who for years are not remembered despite the electioneering campaign promises by the political class.

\section{Loan Facilities}

Sustainable agricultural practices and food sufficiency is often made easy through loan procurement. These loans can be obtained from farmers Multipurpose Cooperative Societies or the Micro Finance Banks established to serve the farmers at the grassroots. This will help farmers to buy new and improved variety of crops, acquire new farm lands, and take responsibility for farm activities. Regrettably, loan facilities have been prebendalized. Only tribal kinsmen or friends can access loan depending on who is at the helm of affairs. The prebendal method of acquiring loan constantly frustrates the goal of women farmers in the State.

Those who lack access to established loan facilities often resort to private money lending groups whose rate of interest and loan conditions are so hazardous and difficult to fulfill. The result is that most women in agriculture and food sufficiency suffer losses and indebtedness due to inability to repay the loan. This creates a vicious circle among the women which is difficult to break because of the web of poverty.

The State has a responsibility to its citizens. Every good government is usually aimed at improving the lot of the citizens as well as yearns to the sufferings of the poor. Women in agriculture and food sufficiency have been in the wood for long. Therefore, the State should collaborate adequately with loan providers to ensure that women in agriculture and food sufficiency easily access loan at affordable conditions. This is the only way to assist farmers and avoid the principle of "godfatherism" which at present is prevalent due to the politicization of the society.

\section{Making land available to women}

Land is a major challenge to women in agriculture. In Nigeria, government has substantial control over land. The state therefore should make land available to women in commercial agriculture if it is ready to address the SDG 2 of zero hunger.

\section{CONCLUSION}

Agriculture as an ancient practice of farming is the major source of food sufficiency in Cross River State. Experience shows that women in the State are taking the lead in agriculture and contributing to food sufficiency. Indeed, food sufficiency in major urban centers in the State 
owes much to the role of women in agriculture. Women form farmers' cooperative societies and also demonstrate strength in terms of labour input. Traditionally, many women form team labour groups to ease farm activities because of shortage of funds. These activities of the women greatly promote agriculture and food sufficiency in the State. There are however, some challenges women face in the farming process such as limited access to land, lack of capital /access to credit, lack of storage facilities etc.

Despite the noble role of women in agriculture and food sufficiency, women are scarcely recognized by their male counterparts in the society due to gender inequality, inheritance and cultural value of preferring male children over female children. Generally, the practice of preferring male children cut across the State because of the right to inheritance and continuity of a family system when the parents die.

Nevertheless, there is need to recognize women's role in agricultural practices in the State. This will improve household income and reduce hunger and poverty which in turn will reduce crime among the youths in the society. To achieve this goal, there is need for a strategic framework which will involve establishment of farm hiring centers, research, provision of infrastructure, support from extension services, construction of feeder roads, and availability of loan facilities to the deserving women in order to boost agriculture and food sufficiency in Cross River State. This study concludes that women in agriculture in cross river state are substantially contributing to food sufficiency in the state but are highly inhibited by certain challenges that has to be addressed in order to keep pace with SDG 2 of zero hunger.

\section{References}

Agbo, F. U. \& Ihemezie, F. J. (2015). Acess to Credit by Vegetable Farmersin Nigeria: A case study of Owerri Agricultural Zone of Imo State, Nigeria. Asian Journal of Agricultural Research. 9(4).Pp.155-165.

AgroNigeria (2016). The Role of Women in Agriculture. www.agroNigeria.com.ng

Ballenger, N., \& Ritten, C. (2014). Bucking the trend: Wyoming sees increase in women as principal operators. Cow Country, 13.

Bastidas, E. P. (1999). Gender Issues and Women's Participation in Irrigated Agriculture: The Case of Two Private Irrigation Canals in Carchi, Ecuador. International Irrigation Management Institute, Research Report No.31. Colombo: IWMI.

Booth, J. G. and Protais,. M. J. (2000). The Economic Role of Women in Agricultural and Rural Development: Promoting Income-Generating Activities. Technical Center for Agricultural and Rural Cooperation (CTA). Seminar Paper, Athens. 18-22 Oct, 1999.

Boserup, E. (1970). Women's Role in Economic Development. Male and Female farming systems. London: Earthscan.

Dahlberg, F. (1981). Woman the gatherer. Yale University Press.

Deere, C. D. (2009). The Gendered impacts of Liberalization. The feminization of Agriculture: The Impact of Economic Restructuring in Rural Latin America. In The Gendered impacts of Liberalization. United Nations Institute for Social Development. Pp. 99-127.

Damisa, M. A., R. Sammdi \& M. Yohanna,(2007). Women Participation in Agricultural Production: A Pobit Analysis. Journal of Applied Sciences. 7(3). Pp. 412-416.

Chikwendu, D. O. \& Arokoyo, J. O. (2008). Women and Sustainable Agricultural Development in Nigeria. Journal of Sustainable Agriculture 11(1) pp. 53-69.

Effiong J. B. (2013). Challenges and prospects of Rural Women in Agricultural Production in Nigeria. Lwati: Journal of contemporary Research. 10(2).

Eteng, F. O. \& Adie, H. I. (2016). "Prebendal Politics, Poverty Pervasiveness and Eradication in Cross River State, Nigeria”. International Journal of Education and Research Vol. 4, No. 1, pp 75-86.

Etuk, E. B. "Strategy for Food Security and Poverty Alleviation: The Livestock Production Option" in James, B. D. (2013) Research for Development (R4D) Responses To Food Security And Poverty Reduction In Africa. (FUTO Press Ltd, Owerri, Nigeria) pp 213-221. 
FAO, (1999). Poverty reduction and Irrigated Agriculture, International Programme for Technology and Research in Irrigation and Drainage (IPTRID). Issue Paper No.1

Hansen, C. W., Jensen, P. S., \& Skovsgaard, C. (2012). Gender roles and agricultural history: The neolithic inheritance. University of Copenhagen, 1-26.

Imonikebe, B. U. (2010). Constraints of Rural Women Farmers' involvement inFood Production in Nigeria. African Research Review. 4(36), Pp. 281-288.

International assessment of agricultural knowledge science and technology for development (2009). Sub-Saharan Africa Report, p. 52 Washington: Island press.

James, B. D (2013), Research for Development (R4D) Responses To Food Security And Poverty Reduction In Africa. (FUTO Press Ltd, Owerri, Nigeria)

Kemi, A. O. (2017). Nigerian Women in Agriculture: Challenges and Way Forward. Journal of Humanities and Social Science 2291) pp. 102-106.

Mechlem, K. (2004) "Food Security and the Right to Food in the Discourse of the United Nations", European Law Journal, 10(5)

Michalopoulos, S. (2018). Worlwide study: Women say Gender discrimination persists in Agriculture. www.euractiv.com

Mtshali, S. M. (2002). Household Livelihood Security in Rural KwaZulu-Natal, South Africa. Wageningen, Ph.D Dissertation, Wageningen Universiteit.

Mutangadura, G. (2004). Women and Land Tenure Rights in Southern Africa: A Human Rights-based Approach, Land in Africa : Land in Africa: Market Asset, or Secure Livelihood? Conference paper, Church House, Westminister, London. November 8-9 2004.

Mwangi, J. G. \& Maina, S. W. "Improving Food Security Through Research and Extension Education: Effects of Climate Change and Aflatoxins" in James, B. D (2013), Research For Development (R4D) Response To Food Security And Poverty Reduction In Africa (FUTO Press, Owerri, Nigeria) Pp 79-92.

Nnadozie, B and Ibe, I. (2000). Women in agriculture: Problems and prospects. Agricultural Transformation in Nigeria. Owerri, Imo State. International and Social Affairs Journal, pp: 12

Ogunlela, Y. I. \& Mukhtar, A. A. (2009) “Gender Issues in Agriculture and Rural Development in Nigeria: The Role of women” (Humanity \& Social Sciences Journal Vol. 4, No 1) pp 19-30.

Olufemi, O (2013) Concepts in Food Security, Kraft Books Limited, Ibadan, Nigeria.

Onyemobi, F. I. (2000). Women in Agriculture and Rural Development. Towards Agricultural Revolution in Nigeria. Enugu Nigeria: Falude publishers.

Ravazi, S. (2009). The Gendered impacts of liberalization: Towards "Embedded Liberalism". In The Gendered impacts of Liberalization. United Nations Institute for Social Development pp.1-34.

Reardon, T. \& S. A. Vosti (1995). Links between rural poverty and the environment in Developing countries: Assets Categories and Investment Poverty. World Development, 23(9). Pp. 1495-1506.

Robinson-part, A. (2016). Learning knowledge and skills for agriculture to improve rural livelihood; UNESCO.

Rwelamira, J. K., Phosa, M. M., Makhura, M. T. and Kirsten, J. F. (2000). Poverty and Inequality Profile of Households in the Northern Province of South Africa. Agrekon 39 (4) pp 529-537.

Shezongo-Macmillan, J. (2005). Women's Property Rights in Zambia. Paper presented to the Strategic Litigation Workshop, 14-18 August, Johannesburg, South Africa.

Stats SA (Statistics South Africa). (2007). Labour Force Survey, March 2007. http://www.statssa.gov.za/publications/P0210/P0210March2007.pdf. Accessed 11/11/2018.

Whitehead, A. (2009). The Gendered impacts of Liberalization Policy on African Agricultural Economies and Rural Livelihoods. In the Gendered Impact of liberalization. United Nations Institute for Social Development.

World Bank (1986). Poverty and Hunger: Issues and Options for Food Security in Developing Countries. Washington, DC.

World Bank, FAO \& IFAD (2009). Gender in Agriculture. Sourcebook. Washington, DC. World Bank.

Zwarteveen, M. (1996). A Plot of One's Own: Gender Relations and Irrigated Land Allocation Policies in Burkina Faso. Research Report No. 10, International Irrigation Management Institute, Colombo, Sri Lanka. 